\title{
Replacement of fish meal by protein soybean concentrate in practical diets for Pacific white shrimp
}

\author{
Mariana Soares ${ }^{1}$, Débora Machado Fracalossi ${ }^{1}$, Luiz Eduardo Lima de Freitas ${ }^{1,2}$, Marysol \\ Santos Rodrigues ${ }^{1}$, Joselle Cursino Redig ${ }^{1}$, José Luiz Pedreira Mouriño1, Walter Quadros \\ Seiffert ${ }^{1}$, Felipe do Nascimento Vieira ${ }^{1}$
}

\footnotetext{
1 Universidade Federal de Santa Catarina, Centro de Ciências, Departamento de Aquicultura, Florianópolis, SC, Brasil.

${ }^{2}$ Empresa Brasileira de Pesquisa Agropecuária, Embrapa Pesca e Aquicultura, Palmas, TO, Brasil.
}

\begin{abstract}
The objective of this work was to evaluate the performance of Litopenaeus vannamei fed different levels $(0,25,50,75$, and $100 \%)$ of soybean protein concentrate $(63.07 \%$ crude protein, CP) to replace fish meal-by product $(61.24 \% \mathrm{CP})$. The study was conducted in clear water in fifteen $800 \mathrm{~L}$ tanks equipped with aeration systems, constant heating $\left(29^{\circ} \mathrm{C}\right)$, and daily water exchange $(30 \%)$. Each tank was stocked with $37.5 \mathrm{shrimp} / \mathrm{m}^{3}(3.03 \pm 0.14 \mathrm{~g})$. Feed was supplied four times a day, at $6 \%$ of the initial biomass, adjusted daily. After 42 days, the weight gain of shrimp fed diets with 0 and $25 \%$ protein replacement was higher than that observed in shrimp fed $100 \%$ replacement, and there were no differences among those fed the other diets. Feed efficiency and survival did not differ among shrimp fed different protein replacements. There was a negative linear trend for growth parameters and feed intake as protein replacement with soybean protein concentrate increased. Fish meal by-product can be replaced by up to $75 \%$ of soybean protein concentrate, with no harm to the growth of Pacific white shrimp.
\end{abstract}

Key Words: Glycine max, growth, Litopenaeus vannamei, nutrition, protein replacement

\section{Introduction}

Success in L. vannamei production is related to proper management practices, water quality, breeding, and efficient diets. One of the biggest obstacles is reconciling the intensification of farming and the provision of goodquality diets, given that artificial feed is essential for success in semi-intensive and intensive production systems (Sookying and Davis, 2011).

Fish meal is currently one of the major sources of animal protein used in diets for marine shrimp (Sá et al., 2013). Protein is the most expensive ingredient in the diet, and its quality is a very important nutritional aspect in aquaculture (Gomez et al., 2008). Much of the raw material used in the production of this input comes from pelagic fishing (Tacon and Metian, 2008). However, fish meal production has declined by an average of $1.7 \%$ per year over the past 15 years (1994-2009), limiting the supply of this input and thus increasing its cost (FAO, 2012). This reality can make the production of many aquatic species economically unfeasible. To solve this problem, studies

Received March 24, 2015 and accepted June 29, 2015.

Corresponding author: felipe.vieira@ufsc.br

http://dx.doi.org/10.1590/S1806-92902015001000001

Copyright (C) 2015 Sociedade Brasileira de Zootecnia. This is an Open Access article distributed under the terms of the Creative Commons Attribution License (http://creativecommons.org/licenses/by/4.0/), which permits unrestricted use, distribution, and reproduction in any medium, provided the original work is properly cited. have been conducted to evaluate the replacement of fish meal protein by other sources of animal and/or vegetable origin (Gatlin III et al., 2007).

Among the plant protein sources, soybean protein concentrate and soybean meal are noteworthy because of the wide availability of soybeans in the market. However, soybean protein concentrate is a more refined protein source, with up to $65 \%$ protein content and a reduced concentration of anti-nutritional factors (NRC, 2011). When compared with fish meal, soybean protein concentrate is deficient in methionine (Drew et al., 2007). However, it has a low carbohydrate and fiber content, high digestibility, and a good amino acid balance, compared with other protein sources of vegetable origin (Gamboa-Delgado et al., 2013). Despite these advantages, not much is known about the use of this ingredient in marine shrimp farming, including Pacific white shrimp.

The objective of this study was to evaluate the performance of Litopenaeus vannamei fed different levels $(0,25,50,75$, and $100 \%)$ of soybean protein concentrate (63.07\% crude protein, $\mathrm{CP}$ ) replacing fish meal protein $(61.24 \% \mathrm{CP})$.

\section{Material and Methods}

We used a shrimp species (Litopenaeus vannamei) from a specific pathogen-free (SPF) line, free of notifiable 
diseases (WSSV, IMNV, YHV, TSV, and IHHNV) by the World Organization for Animal Health (OIE), from Aquacultura Ltda (Rio do Fogo-RN, Brazil).

Five diets containing $30 \%$ digestible protein with 0 , $25,50,75$, and $100 \%$ replacement of fish by-product meal $(61.24 \% \mathrm{CP})$ by soybean protein concentrate $(63.07 \% \mathrm{CP})$ were tested. The production of the diet and the chemical composition analyses of both ingredients followed standard procedures (AOAC, 1999).

Diets were formulated with the commercial feed Feedsoft ${ }^{\circledR}$ Professional version 3.14 (Feedsoft Corporation, Richardson, TX, USA), based on recommendations and nutritional requirements for the good performance of Pacific white shrimp (Fox et al., 1995; NRC, 2011; Zhou et al., 2012). The digestibility of protein sources used in the diet formulation of this experiment was previously assessed by the same team of the marine shrimp laboratory.
Five diets were formulated in this study. The control diet contained $35.41 \%$ fish by-product meal and was free of soybean protein concentrate (Table 1). Four isonitrogenous diets were formulated from the control diet to replace fish meal protein content by soybean protein concentrate at the levels of $25 \%, 50 \%, 75 \%$, and $100 \%$. The same amounts of the other ingredients were used, except for kaolin, which was used as an inert filler to complete the formulation. The essential amino acid profile of each ingredient was calculated, based on the composition of the ingredients used, according to Rostagno et al. (2011), except the essential amino acid profile of the soybean protein concentrate, which was determined by the SAMITEC Institute (Santa Maria, RS). The amino acid profiles for the experimental diets were not analyzed, but they were calculated according to the amino acid profile of each ingredient (Table 2).

Table 1 - Ingredient ( $\left.100 \mathrm{~g}^{-1}\right)$, centesimal composition of diets with different levels $(0,25,50,75$, and $100 \%)$ of soybean protein concentrate replacing fish by-product meal protein and proximal composition of ingredients used in the preparation of experimental diets

\begin{tabular}{|c|c|c|c|c|c|c|c|c|}
\hline \multirow[b]{2}{*}{ Ingredient } & \multicolumn{5}{|c|}{ Substitution (\%) } & & & \\
\hline & 0 & 25 & 50 & 75 & 100 & & & \\
\hline Soybean meal $^{1}$ & 12.00 & 12.00 & 12.00 & 12.00 & 12.00 & & & \\
\hline Wheat bran ${ }^{1}$ & 30.51 & 30.46 & 37.84 & 36.49 & 40.15 & & & \\
\hline Fish meal ${ }^{1}$ & 35.41 & 26.56 & 17.70 & 8.85 & 0.00 & & & \\
\hline Soybean protein concentrate ${ }^{2}$ & 0.00 & 8.85 & 17.70 & 26.56 & 35.41 & & & \\
\hline Cod liver oil ${ }^{3}$ & 1.00 & 1.00 & 1.00 & 1.00 & 1.00 & & & \\
\hline Soybean oil & 1.45 & 2.22 & 2.40 & 2.80 & 3.20 & & & \\
\hline Kaolin $^{4}$ & 14.00 & 13.31 & 5.76 & 6.71 & 2.65 & & & \\
\hline Carboxymethylcellulose ${ }^{5}$ & 0.50 & 0.50 & 0.50 & 0.50 & 0.50 & & & \\
\hline Monocalcium phosphate ${ }^{5}$ & 2.00 & 2.00 & 2.00 & 2.00 & 2.00 & & & \\
\hline Soy lecithin ${ }^{2}$ & 1.53 & 1.53 & 1.53 & 1.53 & 1.53 & & & \\
\hline Premix $^{6}$ & 1.50 & 1.50 & 1.50 & 1.50 & 1.50 & & & \\
\hline Vitamin $\mathrm{C}^{5}$ & 0.06 & 0.06 & 0.06 & 0.06 & 0.06 & & & \\
\hline \multicolumn{6}{|c|}{ Centesimal composition $(\%$, in the dry matter $)$} & $\mathrm{SM}^{9}$ & $\mathrm{SPC}^{10}$ & $\mathrm{FM}^{9}$ \\
\hline Dry matter & 90.83 & 87.64 & 90.69 & 83.84 & 91.39 & 88.59 & 93.21 & 90.81 \\
\hline Moisture & 9.17 & 12.36 & 9.31 & 16.16 & 8.61 & - & - & - \\
\hline Digestible protein ${ }^{7}$ & 30.98 & 30.28 & 30.96 & 30.02 & 30.01 & - & - & - \\
\hline Crude protein & 31.67 & 35.33 & 36.01 & 38.19 & 38.32 & 51.75 & 63.07 & 61.24 \\
\hline Energy $\left(\mathrm{kcal} \mathrm{kg}^{-1}\right)^{8}$ & 3239.23 & 3244.54 & 3485.18 & 3405.31 & 3521.24 & $4161^{11}$ & 4426 & $4199^{11}$ \\
\hline Crude lipid & 11.25 & 10.56 & 8.22 & 8.81 & 7.93 & 3.48 & 1.38 & 15.35 \\
\hline Crude fiber & 12.16 & 13.50 & 12.34 & 15.76 & 15.41 & 6.85 & 5.82 & - \\
\hline Ash & 26.41 & 24.44 & 16.00 & 15.67 & 10.63 & 6.89 & 6.32 & 22.72 \\
\hline Phosphorus & 0.89 & 0.79 & 0.73 & 0.63 & 0.56 & - & - & - \\
\hline
\end{tabular}

SM - soybean meal; SPC - soybean protein concentrate; FM - fish meal.

${ }^{1}$ Nicoluzzi Rações Ltda (Penha, SC, Brazil).

${ }^{2}$ IMCOPA - Importação, Exportação e Indústria de Óleos S.A. (Araucária, PR, Brazil).

${ }^{3}$ Delaware Ltda (Porto Alegre, RS, Brazil)

${ }^{4}$ Vita Essência Farmácia de Manipulação e Homeopatia Ltda (Florianópolis, SC, Brazil)

${ }^{5}$ Labsynth Produtos para Laboratórios Ltda (Diademas, SP, Brazil).

${ }^{6}$ Rovimix Camarão Intensivo DSM Produtos Nutricionais Brasil Ltda (São Paulo, SP, Brazil). Guaranteed levels (according to the manufacturer): vitamin A, 1,250,000 IU; vitamin D3, 350,000 IU; vitamin E, 25,000 IU; vitamin K3, $500.0 \mathrm{mg}$; vitamin B1, 5,000.0 mg; vitamin B2, 4,000.0 mg; vitamin B6, $10.0 \mathrm{mg}$; nicotinic acid, $15,000.0 \mathrm{mg}$; pantothenic acid, 10,000.0 mg; biotin, $150.0 \mathrm{mg}$; folic acid, 1,250.0 mg; vitamin C, 25,000.0 mg; choline, 50,000.0 mg; inositol, 20,000.0 mg; iron, 2,000.0 mg; copper, 3,500.0 mg; chelated copper, 1,500.0 mg; zinc, 10,500.0 mg; chelated zinc, 4,500.0 mg; manganese, 4,000.0 mg; selenium, $15.0 \mathrm{mg}$; chelated selenium, $15.0 \mathrm{mg}$; iodine, $150.0 \mathrm{mg}$; cobalt, $30.0 \mathrm{mg}$; chromo, $80.0 \mathrm{mg}$; excipient q.s., 1,000.0 g.

${ }^{7}$ Protein digestibility: soybean protein concentrate $(75.73 \%)$ and fish meal $(90.76 \%)$

${ }^{8}$ Energy digestibility: soybean protein concentrate $(66.45 \%)$ and fish meal $(87.44 \%)$

${ }^{9}$ Nicoluzzi Rações Ltda (Penha, SC, Brazil).

${ }^{10}$ IMCOPA - Importação, Exportação e Indústria de Óleos S.A. (Araucária, PR, Brazil).

${ }^{11}$ According to Rostagno (2011). 
The ingredients of the diets were crushed and passed through a $600-\mu \mathrm{m}$ sieve. First, the dry ingredients were weighed and mixed. They were then combined with oils, lecithin, and $25 \%$ water. Subsequently, all of the diets were homogenized in an industrial mixer for 20 min and then extruded (Inbramaq, MX-40) in a $1.5 \mathrm{~mm}$ matrix, resulting in a $2.00-\mathrm{mm}$ high-density pellet $(0.5 \mathrm{~mm}$ expansion). The diets were dried in an oven at $50{ }^{\circ} \mathrm{C}$ for $2 \mathrm{~h}$. They were then stored in plastic bags at $-20{ }^{\circ} \mathrm{C}$ until use.

Fifteen ponds, each with 800 -L of useful capacity, were used in the experiment. The ponds were equipped with aeration and water heating systems. Each pond was stocked with 30 shrimp $(3.03 \pm 0.14 \mathrm{~g}$ average weight). The treatments were randomly distributed among the ponds in triplicate.

The shrimp were fed four times a day $(08.00 \mathrm{~h}, 11: 00 \mathrm{~h}$, 14:00 $\mathrm{h}$, and $17.00 \mathrm{~h}$ ) with the aid of feed trays for better provision $\left(\right.$ area $\left.=0.03 \mathrm{~m}^{2}\right)$. Diets were initially supplied in an amount equivalent to $6 \%$ of the biomass, adjusted daily according to the daily feed intake.

Water was exchanged once daily, until all the organic matter content (leftover feed, feces, and seedlings) were removed from the water, meaning about $30 \%$ of the total volume of water was replaced. The water quality variables, such as dissolved oxygen concentration and temperature, were evaluated twice daily. The salinity, $\mathrm{pH}$, total ammonia and nitrite were monitored once a week.

Ten shrimp per pond were sampled weekly. Concerning biometrics, the mean of the samples was adopted as the weekly weight. After the six weeks of rearing in clear water, the following performance parameters were evaluated: total weight gain $(\mathrm{g})$, weekly weight gain (g/week), final weight gain (g), survival (\%), feed efficiency, and feed intake $(\mathrm{g})$.
Analysis of the diets followed the AOAC (1999) methodology. The diets were subjected to analyses of dry matter (drying at $105^{\circ} \mathrm{C}$ ), ash (burning at $550{ }^{\circ} \mathrm{C}$ ), protein (Kjeldahl, $\mathrm{N} \times$ 6.25), ether extract (Soxleth, after acid hydrolysis), fiber (acid detergent acid), and gross energy (adiabatic bomb calorimeter).

First, the homoscedasticity of variances was found by the Bartlett test. Data of animal performance and water quality were assessed by one-way ANOVA and the means were separated by Tukey's test, both at a significance level of $5 \%$. The weight gain and feed intake data were also subjected to linear regression analysis, and the estimated coefficients had their significance assessed by the test $(\alpha<0.05)$. The software Statistica (version 10.0) was used for all statistical analyses.

\section{Results and Discussion}

The diets had the same level of digestible protein, while digestible energy varied by $282 \mathrm{kcal} \mathrm{kg}^{-1}$, which met the nutritional requirement for L. vannamei (NRC, 2011). The ether extract content varied among all the diets, but within the range allowed for the proper performance of penaeid shrimp (Sheen et al., 1994) (Table 2). Other authors suggest between 8 and $10 \%$ of ether extract as optimal for proper growth of $P$. monodon (Glencross et al., 2002). Even considering the requirement of $n-3$ for good performance of penaeid shrimp, the diets did not maintain the n-3/n-6 fatty acids, which may have influenced the performance of animals fed diets with higher replacement of fish meal by soy protein concentrate.

The water quality parameters dissolved oxygen concentration $(4.98-7.02 \mathrm{mg} / \mathrm{L})$, temperature $\left(28.02-30.0{ }^{\circ} \mathrm{C}\right)$, salinity (35 ppt), $\mathrm{pH}(7.74-8.36)$, total ammonia $(0.34-1.23 \mathrm{mg} / \mathrm{L})$, and nitrite $(0.00-0.07 \mathrm{mg} / \mathrm{L})$ showed no difference among

Table 2 - Essential amino acid profiles projected for each formulated diet

\begin{tabular}{|c|c|c|c|c|c|c|c|}
\hline \multirow{2}{*}{ Essential amino acid } & \multicolumn{7}{|c|}{$\mathrm{g} \mathrm{kg}^{-1}$ as fed } \\
\hline & $0 \%$ & $25 \%$ & $50 \%$ & $75 \%$ & $100 \%$ & Requirement $^{1}$ & References \\
\hline Arginine & 21.7 & 21.6 & 22.5 & 22.4 & 21.7 & 19.0 & Zhou et al., 2012 \\
\hline Histidine & 7.8 & 8.1 & 8.8 & 9.1 & 9.3 & 7.0 & NRC, 2011 \\
\hline Isoleucine & 13.5 & 13.8 & 14.5 & 14.9 & 15.1 & 10.8 & NRC, 2011 \\
\hline Leucine & 23.7 & 24.2 & 25.6 & 26.2 & 26.5 & 16.0 & NRC, 2011 \\
\hline Lysine & 21.3 & 20.9 & 21.1 & 20.8 & 20.5 & 16.0 & NRC, 2011 \\
\hline Methionine $^{2}$ & 7.4 & 6.6 & 6.0 & 5.3 & 4.3 & 6.0 & - \\
\hline Methionine + cystine & 11.7 & 11.0 & 10.7 & 10.1 & 9.0 & 8.8 & NRC, 2011 \\
\hline Phenylalanine & 13.7 & 14.3 & 15.4 & 16.1 & 16.5 & 12.3 & NRC, 2011 \\
\hline Threonine & 13.2 & 12.5 & 12.3 & 11.6 & 10.6 & 11.0 & NRC, 2011 \\
\hline Tryptophan & 3.8 & 4.0 & 4.5 & 4.8 & 4.9 & 3.0 & NRC, 2011 \\
\hline Valine & 16.3 & 16.0 & 16.4 & 16.2 & 15.6 & 12.0 & NRC, 2011 \\
\hline
\end{tabular}

${ }^{1}$ Essential amino acid requirement for marine shrimp Penaeus monodon with protein correction for Litopenaeus vannamei.

${ }^{2}$ Methionine requirement for methionine + cystine. 
the treatments $(\mathrm{P} \geq 0.05)$, remaining within the recommended limits for the farming of this species.

The weekly growth of shrimp in all treatments was higher than $1 \mathrm{~g}$ per week, showing that the diets used in this experiment provided satisfactory growth to the shrimp. The weekly growth was higher those that reported in other studies for Pacific white shrimp (Samocha et al., 2004; Suárez et al., 2009; Bauer et al., 2012).

A negative linear trend was found for final weight (Figure 1A), weekly weight gain, total weight gain and feed intake as replacement of fish meal by-product meal by soybean protein concentrate was increased (Table 3 ). However, replacing up to $75 \%$ of fish meal by soybean protein concentrate did not impair shrimp growth (Table 3).

The reduced growth found in this study may be related to the lack of supplementation of methionine and threonine in diets with higher levels of replacement of fish meal by-product meal by soybean protein concentrate. Soybean protein concentrate is deficient in methionine and threonine, and its supplementation is suggested in the formulation of diets for some species, especially carnivores (Gatlin III et al., 2007).

Since amino acid requirements have not been established for white shrimp, it is assumed that the amount in this diet with $100 \%$ replacement of fish meal was not adequate for the best performance. Concerning the formulation of experimental diets, the methionine requirement was based on the requirement for P. monodon $(0.7 \%$ of diet). A mathematical conversion was made according to the requirements for digestible protein of $L$. vannamei; therefore, a value was estimated for its requirement in methionine $(0.6 \%$ of diet). The absolute requirement for methionine estimated for $L$. vannamei in this study was achieved only in the control diet, and in those with $25 \%$ and $50 \%$ replacement of fish meal by-product meal by soybean protein concentrate. However, the concentration of methionine + cystine was met in all of the diets, theoretically supplying the requirement for methionine. Nevertheless, the concentration of these amino acids in the diet with $100 \%$ protein replacement did not reach the minimum required for good growth performance.

However, studies have found that when fed diets containing the same replacement levels of fish meal by

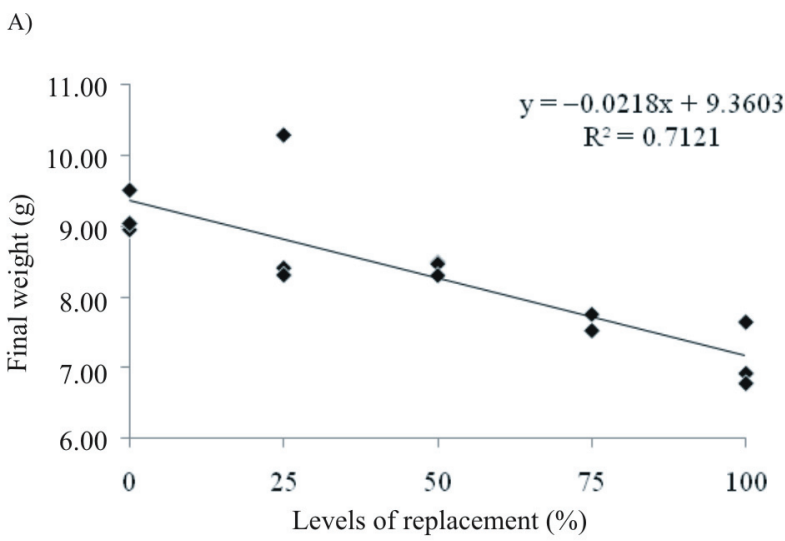

B)

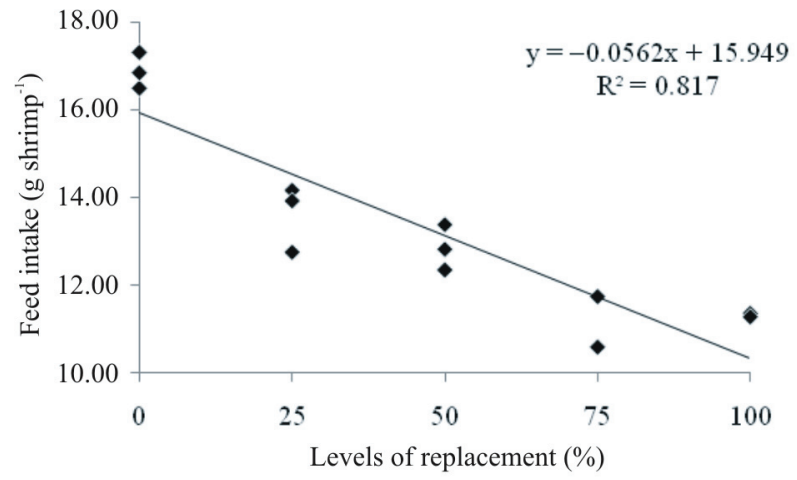

All regression coefficients are significant by the t test $(\mathrm{P}<0.05)$.

Figure 1 - Final weight (A) and feed intake (B) of Pacific white shrimp fed different levels $(0,25,50,75$, and $100 \%)$ of soybean protein concentrate $(63.07 \% \mathrm{CP})$ replacing fish by-product meal protein $(61.24 \%$ crude protein $)$.

Table 3 - Performance of Pacific white shrimp fed different levels $(0,25,50,75$, and 100\%) of soybean protein concentrate $(63.07 \%$ CP) replacing fish by-product meal protein $(61.24 \%$ crude protein)

\begin{tabular}{|c|c|c|c|c|c|c|c|}
\hline & \multicolumn{5}{|c|}{ Substitution (\%) } & \multirow{2}{*}{ P-value } & \multirow{2}{*}{ Linear effect } \\
\hline & 0 & 25 & 50 & 75 & 100 & & \\
\hline Final weight (g) & $12.11 \pm 0.45 \mathrm{a}$ & $12.12 \pm 1.20 \mathrm{a}$ & $11.49 \pm 0.21 \mathrm{ab}$ & $10.57 \pm 0.05 \mathrm{ab}$ & $10.15 \pm 0.34 b$ & 0.015 & $\begin{array}{c}\mathrm{y}=-0.0229 x+12.477 \\
R^{2}=0.6308\end{array}$ \\
\hline Weekly growth (g/week) & $1.53 \pm 0.05 \mathrm{a}$ & $1.50 \pm 0.19 \mathrm{a}$ & $1.40 \pm 0.02 \mathrm{ab}$ & $1.27 \pm 0.03 \mathrm{ab}$ & $1.18 \pm 0.08 \mathrm{~b}$ & 0.010 & $\begin{array}{c}y=-0.0036 x+1.5601 \\
R^{2}=0.7121\end{array}$ \\
\hline Survival (\%) & $100 \pm 0.00 \mathrm{a}$ & $96.67 \pm 3.33 \mathrm{a}$ & $97.78 \pm 1.92 \mathrm{a}$ & $96.67 \pm 3.33 \mathrm{a}$ & $98.89 \pm 1.92 \mathrm{a}$ & 0.424 & No significance \\
\hline Apparent feed efficiency & $0.74 \pm 0.00 \mathrm{a}$ & $0.77 \pm 0.01 \mathrm{a}$ & $0.76 \pm 0.02 \mathrm{a}$ & $0.79 \pm 0.05 \mathrm{a}$ & $0.75 \pm 0.02 \mathrm{a}$ & 0.176 & No significance \\
\hline
\end{tabular}

Means within columns followed by different letters are different by Tukey's test $(\mathrm{P}<0.05)$.

All regression coefficients are significant by the test $(\mathrm{P}<0.05)$.

Values presented as mean \pm standard deviation. 
soybean protein concentrate but with supplementation of essential amino acids (methionine, arginine, and phenylalanine), Pacific white shrimp also showed a reduction in weight gain in the treatment with $100 \%$ fish meal replacement (Forster et al., 2002). Another study, using the same species and levels of replacement by soybean protein concentrate equal to those used in this study, but with different levels from the nutritional requirements for lysine, histidine, phenylalanine, and methionine in some diets tested, showed no significant differences in growth between treatments (Bauer et al., 2012). Thus, it is assumed that a factor other than the absence of an essential amino acid is limiting growth. The difference in the marine source of fat found between diets may have contributed to the results of this study. Therefore, all diets containing $1 \mathrm{~g}$ fish oil, but diets without replacement of fish meal, contained more fat of marine origin. Sá et al. (2013) found that fish meal can be completely replaced by soy protein concentrate when the minimum levels of fish oil are met, without undermining shrimp growth.

The feed intake of diets with high levels of protein replacement was lower in this study (Figure 1B), which is likely to have contributed to the reduction in shrimp growth. Diets formulated with high levels of soybean-derived ingredients may present palatability problems (McGoogan and Gatlin 1997; Nunes et al., 2006). The removal of specific carbohydrates that occurs in the processing of soybean protein concentrate may reduce palatability, which is frequently reported when vegetable protein sources are used for aquatic species (Forster et al., 2002).

In a recently published study, no significant difference for the growth of Pacific white shrimp was found when they were fed diets containing the same levels of replacement of fish meal by soybean protein concentrate as in this study, with supplementation of essential amino acids and addition of an attractive ingredient. It was found that the feed intake by white shrimp did not differ between the diets offered, suggesting similar attractiveness (Bauer et al., 2012; Sá et al., 2013), different from what was found in this study.

Similar results were found for $P$. monodon, which showed a reduction in feed intake and lower weight gain when fed diets with high levels of soybean protein concentrate (Paripatananont et al., 2001). The same response was reported by Forster et al. (2002) for $L$. vannamei fed the same levels of replacement of fish meal by soybean protein concentrate, in which the reduction in feed intake was associated with a lower specific growth rate.
The survival and feed efficiency did not differ significantly among treatments $(\mathrm{P} \geq 0.05)$. These results corroborate other studies with the same species, in which the soybean protein concentrate was the main protein source in the diet (Bauer et al., 2012; Sookying and Davis, 2012; Sá et al., 2013).

High levels of inclusion of soybean protein, without the use of fish meal, are usually tolerated and result in good performance results when the nutritional requirements of shrimp are properly balanced (Sookying and Davis, 2012).

Other studies that replaced fish meal by alternative protein sources, mainly those of plant origin in shrimp diets, have been carried out (Lim and Dominy, 1990; Samocha et al., 2004; Amaya et al., 2007; Suárez et al., 2009; Sookying and Davis, 2011; Bauer et al., 2012; Liu et al., 2012; Sá et al., 2013; Sookying et al., 2013). However, the obtained results vary according to the species and developmental stage, the composition of the diet formulations, the quality of the tested ingredients, the feeding management, and the farming conditions (Lim and Dominy, 1990). In this study, the growth of Pacific white shrimp $(3.03 \pm 0.14 \mathrm{~g}$ to $11.18 \pm 1.24 \mathrm{~g})$ in clear water showed good results for the growth performance of the species when fed diets containing up to $75 \%$ replacement of fish meal.

The use of diets for shrimp with low or no inclusion of fish meal allows producers to reach new markets that are willing to pay a higher price for shrimp fed and produced under conditions that do not represent a threat to wild fish stocks and the environment (Amaya et al., 2007). Furthermore, as the use of soy protein concentrate increases in aquaculture and at lower prices, the cost of supplementation with marine oils, synthetic amino acids, and attractive ingredients will be offset by lower dependence on fish meal in shrimp feed formulations (Sá et al., 2013).

\section{Conclusions}

The Pacific white shrimp shows lower growth as the levels of replacement of fish meal by-product protein by soybean protein concentrate in the diet are increased. However, shrimp show good growth performance at up to $75 \%$ of replacement of fish meal by concentrated soybean protein. The good results achieved in this study were obtained without supplementation of essential amino acids, confirming that soybean protein concentrate can be properly used for the species. 


\section{Acknowledgments}

The authors thank Importação, Exportação e Indústria de Óleos Ltda (IMCOPA) for their financial support. Mariana Soares and Marysol Rodrigues received a fellowship from Coordenação de Aperfeiçoamento de Pessoal de Nível Superior (CAPES); Joselle Redig received a fellowship from Conselho Nacional de Desenvolvimento Científico e Tecnológico (CNPq); and Felipe Vieira, Walter Seiffert, and José Mouriño received research productivity fellowships from $\mathrm{CNPq}$ (protocol no. PQ 309868/2014-9, 302792/2012-0, 308292/ 2014-6, respectively). The authors acknowledge Nicoluzzi for providing the ingredients used in the experimental diets and Norha Bolivar, Gabriela Soltes, Scheila Pereira, Esmeralda Legarda, and Bruno Corrêa da Silva for technical support.

\section{References}

Amaya, E. A.; Davis, D. A. and Rouse, D. B. 2007. Replacement of fish meal in practical diets for the Pacific white shrimp (Litopenaeus vannamei) reared under pond conditions. Aquaculture 262:393-401. doi: 10.1016/j.aquaculture.2006.11.015.

AOAC - Association of Official Analytical Chemists. 1999. Official methods of analyses. 16th ed. AOAC International, Arlington, VA.

Arruda, L. F.; Borghesi, R.; Portz, L.; Cyrino, J. E. P. and Oetterer, M. 2009. Fish silage in Black Bass (Micropterus Salmoides) feed as an alternative to fish meal. Brazilian Archives of Biology and Technology 52:1261-1266. doi: 10.1590/S151689132009000500025.

Bauer, W.; Prentice-Hernandez, C.; Tesser, M. B.; Wasielesky, W. J. and Poersch, L. H. S. 2012. Substitution of fish meal with microbial floc meal and soy protein concentrate in diets for the pacific white shrimp Litopenaeus vannamei. Aquaculture 342-343:112-116. doi: 10.1016/j.aquaculture.2012.02.023

Cruz-Suárez, L. E.; Tapia-Salazar, M.; Villarreal-Cavazos, D.; Beltran-Rocha, J.; Nieto-López, M. G.; Lemme, A. and Ricque-Marie, D. 2009. Apparent dry matter, energy, protein and amino acid digestibility of four soybean ingredients in white shrimp Litopenaeus vannamei juveniles. Aquaculture 292:87-94. doi: 10.1016/j.aquaculture.2009.03.026.

Drew, M. D.; Borgeson, T. L. and Thiessen, D. L. 2007. A review of processing of feed ingredients to enhance diet digestibility in finfish. Animal Feed Science Technology 138:118-136. doi: 10.1016/j.anifeedsci.2007.06.019.

FAO - Food and Agriculture Organization of United Nations. 2012. The state of World Fisheries and Aquaculture (SOFIA). FAO, Roma. p.24-26.

Forster, I. P.; Dominy, W. and Tacon, A. G. 2002. The use of concentrates and other soy products in shrimp feeds. p.528-540. In: Avances em Nutricion Acuicola VI. Memorias del VI Simposium Internacional de Nutricion Acuicola, Cancun, México.

Fox, J. M.; Lawrance, A. L. and Li-Chan, E. 1995. Dietary requirement for lysine by juvenile Penaeus vannamei using intact and free amino acid sources. Aquaculture 131:279-290. doi: 10.1016/0044-8486(94)00348-R

Gamboa-Delgado, J.; Rojas-Casas, M. G.; Nieto-López, M. G. and Cruz-Suárez, L. E. 2013. Simultaneous estimation of the nutritional contribution of fish meal, soy protein isolate and corn gluten to the growth of Pacific white shrimp (Litopenaeus vannamei) using dual stable isotope analysis. Aquaculture 380-383:33-40. doi: 10.1016/j.aquaculture.2012.11.028.

Gatlin III, D. M.; Barrows, F. T.; Brown, P.; Dabrowski, K.; Gaylord, T. G.; Hardy, R. W.; Herman, E.; Hu, G.; Krogdahk, A.; Nelson, R.; Overturl, K.; Rust, M.; Sealey, W.; Skonberg, D.; Souza, E. J.; Stone, D.; Wilson, R. and Wurtele, E. 2007. Expanding the utilization of sustainable plant products in aquafeeds: a review. Aquaculture Research 38:551-579. doi: 10.1111/j.1365-2109.2007.01704.x.

Glencross, B. D.; Smith, D. M.; Thomas, M. R. and Williams, K. C. 2002. Optimising the essential fatty acids in the diet for weight gain of the prawn, Penaeus monodon. Aquaculture 204:85-99. doi: 10.1016/S0044-8486(01)00644-5.

Gomez, M. G. U.; López-Aceves, L. A.; Ponce-Palafox, J. T.; Rodriguez-Gonzalez, H. and Arredondo-Figueroa, J. L. 2008. Growth of fresh-water prawn Macrobrachium tenellum (Smith, 1871) juveniles fed isoproteic diets substituting fish meal by soya bean meal. Brazilian Archives of Biology and Technology 51:57-65. doi: 10.1590/S1516-89132008000100008.

Huang, Y.; Yin, Z.; Ai, H.; Huang, X.; Li, S.; Weng, S. and He, J. 2011. Characterization of WSSV resistance in selected families of Litopenaeus vannamei. Aquaculture 311:54-60. doi: 10.1016/ j.aquaculture.2010.11.032

Lim, C. and Dominy, W. 1990. Evaluation of soybean meal as a replacement for marine animal protein in diets for shrimp (Penaeus vannamei). Aquaculture 87:53-63. doi: 10.1016/00448486(90)90210-E

Liu, X.; Ye, J.; Wang, K.; Kong, J.; Yang, W. and Zhou, L. 2012. Partial replacement of fish meal with peanut meal in practical diets for the Pacific white shrimp, Litopenaeus vannamei. Aquaculture Research 43:745-755. doi: 10.1111/j.1365-2109.2011.02883.x.

McGoogan, B. B. and Gatlin, D. M. 1997. Effects of replacing fish meal with soybean meal in diets for red drum Sciaenops ocellatus and potential for palatability enhancement. Journal of the World Aquaculture Society 28:374-385. doi: 10.1111/j.1749-7345.1997. tb00284.x.

NRC - National Research Council. 2011. Committee on Nutrient Requirements of Fish and Shrimp. Nutrient requirements of fish and shrimp. 1st ed. NRC National Academic Press, Washington.

Nunes, A. J. P.; Sá, M. V. C.; Andriola-Neto, F. F. and Lemos, D. 2006. Behavioral response to selected feed attractants and stimulants in Pacific white shrimp, Litopenaeus vannamei. Aquaculture 260:244-254. doi: 10.1016/j.aquaculture.2006.06.027.

Olsen, R. L. and Hasan, M. R. 2012. A limited supply of fishmeal: Impact on future increases in global aquaculture production. Trends in Food Science \& Technology 27:120-128. doi: 10.1016/ j.tifs.2012.06.003

Paripatananont, T.; Boonyaratpalin, M.; Pengseng, P. and Chotipuntu, P. 2001. Substitution of soy protein concentrate for fishmeal in diets of tiger shrimp Penaeus monodon. Aquaculture Research 32:369-374. doi: 10.1046/j.1355-557x.2001.00045.x.

Peisker, M. 2001. Manufacturing of soy protein concentrate for animal nutrition. CIHEAM 54:103-107.

Rostagno, H. S.; Albino, L. F. T.; Donzele, J. L.; Gomes, P. C.; Oliveira, R. F. M.; Lopes, D. C.; Ferreira, A. S.; Barreto, S. L. T. and Euclides, R. F. 2011. Tabelas brasileiras para aves e suínos: composição de alimentos e exigências nutricionais. 3.ed. Universidade Federal de Viçosa, Departamento de Zootecnia, Viçosa, MG.

Sá, M. V. C.; Sabry-Neto, H.; Cordeiro-Júnior, E. and Nunes, A. J. P. 2013. Dietary concentration of marine oil affects replacement of fish meal by soy protein concentrate in practical diets for the white shrimp, Litopenaeus vannamei. Aquaculture Nutritions 19:199-210. doi: 10.1111/j.1365-2095.2012.00954.x.

Samocha, T. M.; Davis, A. D.; Saoud, I. P. and Baulta, K. 2004. Substitution of fish meal by co-extruded soybean poultry byproduct meal in practical diets for the Pacific white shrimp, 
Litopenaeus vannamei. Aquaculture 231:197-203. doi: 10.1016/ j.aquaculture.2003.08.023.

Sheen, S. S.; Chen, S. J. and Huang, Y. S. 1994. Effect of dietary lipid levels on the growth response of tige prawn, Penaeus monodon. Journal of the Fisheries Society of Taiwan 21:205-213.

Sookying, D. and Davis, D. A. 2011. Pond production of Pacific white shrimp (Litopenaeus vannamei) fed high levels of soybean meal in various combinations. Aquaculture 319:141-149. doi: 10.1016/j.aquaculture.2011.06.049.

Sookying, D. and Davis, D. A. 2012. Use of soy protein concentrate in practical diets for Pacific white shrimp (Litopenaeus vannamei) reared under field conditions. Aquaculture International 20:357-371. doi: 10.1007/s10499-011-9464-6.

Sookying, D.; Davis, D. A. and Silva, F. S. D. 2013. A review of the development and application of soybean-based diets for Pacif white shrimp Litopenaeus vannamei. Aquaculture Nutrition 19:441-448. doi: 10.1111/anu.12050.

Suárez, J. A.; Gaxiola, G.; Mendoza, R.; Cadavid, S.; Garcia, G.; Alanis, G.; Suarez, A.; Faillace, J. and Cuzon, G. 2009. Substitution of fish meal with plant protein sources and energy budget for white shrimp Litopenaeus vannamei (Boone, 1931). Aquaculture 289:118-123. doi: 10.1016/j.aquaculture.2009.01.001.

Tacon, A. G. J. and Metian, M. 2008. Global overview on the use of fish meal and fish oil in industrially compounded aquafeeds: trends and future prospects. Aquaculture 285:146-158. doi: 10.1016/j.aquaculture.2008.08.015.

Zhou, Q.; Zeng, W.; Wang, H.; Wang, T.; Wang, Y. and Xie, F. 2012. Dietary arginine requirement of juvenile Pacific white shrimp, Litopenaeus vannamei. Aquaculture 364:252:258. doi: 10.1016/ j.aquaculture.2012.08.020. 